\title{
Steatosis and Liver Cancer in Transgenic Mice Expressing the Structural and Nonstructural Proteins of Hepatitis C Virus
}

\author{
HERVÉ LERAT,* MASAO HONDA,\| MICHAEL R. BEARD,* KIM LOESCH,* JIAREN SUN,* \\ YAN YANG, * MICHIARI OKUDA, * RAINER GOSERT,* SHU-YUAN XIAO,§ STEVEN A. WEINMAN, ${ }^{*}$ \\ and STANLEY M. LEMON* \\ Departments of *Microbiology \& Immunology, ${ }^{\ddagger}$ Internal Medicine and Physiology \& Biophysics, and \$Pathology, The University of Texas \\ Medical Branch, Galveston, Texas; and IFirst Department of Internal Medicine, Kanazawa University, Kanazawa 920, Japan
}

\section{See editorial on page 568.}

Background and Aims: The aim of this study was to determine whether expression of hepatitis $C$ virus proteins alters hepatic morphology or function in the absence of inflammation. Methods: Transgenic C57BL/6 mice with liver-specific expression of RNA encoding the complete viral polyprotein (FL-N transgene) or viral structural proteins (S-N transgene) were compared with nontransgenic littermates for altered liver morphology and function. Results: FL-N transcripts were detectable only by reverse-transcription polymerase chain reaction, and $\mathrm{S}-\mathrm{N}$ transcripts were identified in Northern blots. The abundance of viral proteins was sufficient for detection only in S-N transgenic animals. There was no inflammation in transgenic livers, but mice expressing either transgene developed age-related hepatic steatosis that was more severe in males. Apoptotic or proliferating hepatocytes were not significantly increased. Hepatocellular adenoma or carcinoma developed in older male animals expressing either transgene, but their incidence reached statistical significance only in FL-N animals. Neither was ever observed in age-matched nontransgenic mice. Conclusions: Constitutive expression of viral proteins leads to common pathologic features of hepatitis $C$ in the absence of specific anti-viral immune responses. Expression of the structural proteins enhances a low background of steatosis in C57BL/6 mice, while additional low level expression of nonstructural proteins increases the risk of cancer.

$\mathrm{H}$ epatitis $\mathrm{C}$ virus (HCV), a positive-strand RNA virus classified within the family Flaviviridae, is uniquely capable of establishing persistent infections within the human liver. Chronic infection results in necroinflammatory liver disease characterized by the insidious progression of hepatic fibrosis and loss of functioning hepatocyte mass. ${ }^{1-4} \mathrm{~A}$ significant proportion of infected persons ultimately develop cirrhosis, hepatic failure, and/or hepatocellular carcinoma (HCC). ${ }^{5-7}$ These lethal manifestations of hepatitis $\mathrm{C}$ result in approximately 8000-10,000 deaths annually among the 3.9 million Americans infected with this virus. ${ }^{8}$ Hepatitis $\mathrm{C}$ is thus the single most common cause of clinically significant liver disease in the United States today and a major worldwide threat to public health. However, available therapies are expensive, difficult to administer, relatively toxic, and effective in a minority of patients. 9,10

A better understanding of the mechanisms underlying the pathology of chronic hepatitis $C$ would be helpful in designing new strategies for intervening in this disease. However, research efforts have been hampered by the lack of both a cell culture system that is permissive for efficient HCV replication and small animal models that either support replication of HCV or mimic the pathologic features of chronic hepatitis $C$ in humans. ${ }^{11}$ Little is known about the molecular mechanisms underlying the liver injury associated with this viral infection, but a cell-mediated immune response with prominent lymphocytic infiltration of the liver is thought to play a major role in pathogenesis. ${ }^{12,13}$ Like other hepatitis viruses, $\mathrm{HCV}$ may replicate in hepatocytes without inducing significant cytopathology, and inflammation associated with the immune response to the infection could account for most if not all of its pathologic consequences. ${ }^{13,14}$

However, 2 important observations suggest that nonimmune mechanisms also play an important role in pathogenesis. These include the frequent presence of steatosis in chronic hepatitis $\mathrm{C}$, reflecting a metabolic

Abbreviations used in this paper: ALT, alanine aminotransferase; BHT, butylated hydroxytoluene; BrdU, 5'-bromo-2'-deoxyuridine; DAB, 3,3'-diaminobenzidene tetrahydrochloride; DAPI, 4,6'diamidino-2-phenylindole; HCC, hepatocellular carcinoma; MMLV, Maloney murine leukemia virus; RT-PCR, reverse-transcription polymerase chain reaction; SV40, simian virus 40 .

(C) 2002 by the American Gastroenterological Association 0016-5085/02/\$35.00 doi:10.1053/gast.2002.31001 
abnormality that is not observed as often in other inflammatory conditions, such as autoimmune hepatitis or chronic hepatitis B. ${ }^{15-19}$ Some lines of evidence also suggest a distinctive synergy between the liver injury associated with chronic HCV infection and that accompanying alcohol ingestion. ${ }^{20,21}$ This suggests that HCV infection uniquely exacerbates alcohol-related metabolic disturbances.

In addition to these clinical observations, a considerable number of in vitro studies have suggested that the expression of various $\mathrm{HCV}$ proteins in cultured cells may lead to altered lipid metabolism and transport, dysregulation of the cell cycle, either increased or decreased susceptibility to apoptosis, and cellular transformation. ${ }^{22-27}$ However, few data convincingly support a role for any of these effects in human disease. In part, this absence of data stems from the lack of suitable animal models. The chimpanzee (Pan troglodytes) is the only animal species that is clearly permissive for HCV infection. ${ }^{28,29}$ However, unlike humans, infected chimpanzees typically develop minimal liver disease as a result of viral replication.

Given the absence of alternative small animal models, transgenic mice represent a potentially useful model for determining the long-term consequences of HCV protein expression in vivo. Here, we describe in detail 2 transgenic mouse lineages that express HCV proteins under control of the liver-specific murine albumin promoter/enhancer. ${ }^{30}$ Because mice can be expected to be immunologically tolerant to transgenic proteins that are transcriptionally regulated by this promoter, this experimental strategy offers the advantage of providing information on the direct, physiologic impact of HCV protein expression in the absence of confounding factors associated with immunologic responses to the viral proteins. The transgenic animals described in this report express RNAs encoding either the full-length HCV polyprotein or the structural proteins of a genotype $1 \mathrm{~b} \mathrm{HCV}, 31,32$ including the core, and the E1 and E2-p7 envelope proteins. The phenotypes of these transgenic lineages provide strong evidence for nonimmune mechanisms of liver injury in chronic hepatitis $\mathrm{C}$ and suggest an important role for the nonstructural proteins of HCC in hepatocellular carcinogenesis.

\section{Materials and Methods}

\section{Production of Transgenic Mice}

The plasmid pGEMAlbSVPA-B1(-) contains the murine albumin enhancer/promoter ${ }^{30}$ with a downstream SV40 intron/polyadenylation cassette. Complementary DNA (cDNA) corresponding to the full-length polyprotein-coding region (core to NS5B, nts 342-9378) or the structural protein-coding region only (core to $\mathrm{E} 2 / \mathrm{p} 7$, nts 342-2771) of the genotype $1 \mathrm{~b}$, HCV-N strain of HCV 31,32 was inserted into this vector between newly engineered $X h_{0} \mathrm{I}$ sites flanking the albumin enhancer/promoter and SV40 sequence, creating pAlbSVPAHCV and pAlbSVPA-HCV-S, respectively. Purified plasmid DNA (transcriptional units only) was injected into the eggs of F2 hybrid zygotes generated from mating $\mathrm{F}_{1}$ hybrid male and female mice $(\mathrm{C} 3 \mathrm{H} / \mathrm{HeJ} \times \mathrm{C} 57 \mathrm{BL} / 6)$. Offspring were screened for the presence of the transgene by Southern analysis of DNA extracted from tail biopsies after digestion with HindIII. DNA from 15 of 55 potential founder $\left(\mathrm{F}_{0}\right)$ animals obtained after injection of the full-length FL-N construct (pAlbSVPA-HCV), and 12 of 38 potential $F_{0}$ animals obtained after injection of the structural protein construct S-N (pAlbSVPA-HCV-S) contained the cognate transgene.

Transgenic $\mathrm{F}_{0}$ founder animals were mated with normal C57BL/6 mice to produce $\mathrm{F}_{1}$ and subsequent generations of animals. Mice were housed in a controlled, specific, pathogenfree environment, 4 per microfiltered cage, except when animals were mating. Animals were fed regular sterile mouse chow and water. All procedures involving animals were approved by the Institutional Animal Care and Use Committee. The preliminary pathologic findings (steatosis and HCC) in one of these transgenic lineages (FL-N/35) have been reported elsewhere, ${ }^{33}$ but a detailed comparison of the frequency of these findings in transgenic and nontransgenic animals has not been published.

\section{Transgene mRNA Detection}

Total RNA was extracted from approximately $100 \mathrm{mg}$ of liver tissue pulverized in liquid nitrogen using a phenol-free total RNA isolation method (RNAqueous; Ambion, Austin, TX). For Northern blots, total RNA was fractionated in an agarose gel and passively transferred onto positively charged nylon membranes (BrightStar; Ambion) following the Northern MAX (Ambion) protocol. RNA was cross-linked to the membranes by ultraviolet (UV) irradiation at $254 \mathrm{~nm}$ (UV Stratalinker; Stratagene, La Jolla, CA). Hybridization of psoralen-biotin-conjugated DNA probes complementary to nts 407-860 of HCV-N and subsequent visualization of the blot with a streptavidin-alkaline phosphatase conjugate were carried out according to the BrightStar Biodetect Nonisotopic Detection Kit protocol (Ambion). After washing, membranes were incubated with CDP-Star chemiluminescent substrate (Ambion) and exposed to film.

For reverse-transcription polymerase chain reaction (RTPCR), total RNA was purified by 2 cycles of RQ1 DNase digestion, each followed by $\mathrm{LiCl}$ precipitation of RNA. Nine sets of oligonucleotide primers were used to amplify segments of the HCV genome spanning the entire open reading frame. RT was carried out with MMLV reverse transcriptase using a single-tube, 2-compartment RT-PCR procedure (Clontech, Palo Alto, CA). ${ }^{34}$ Parallel PCR reactions were performed without a prior RT step to confirm that the template for PCR amplification products was RNA. PCR products were sepa- 
rated in agarose gels and passively transferred to BrightStar nylon membranes before hybridization to $\mathrm{HCV}$-specific DNA probes.

\section{Necropsy and Histopathology Procedures}

Animals were killed by $\mathrm{CO}_{2}$ asphyxiation, and liver tissue was immediately snap-frozen in liquid nitrogen for RNA isolation and placed in $10 \%$ formalin or OCT cryostat embedding compound (Tissue-Tek, Torrance, CA) for histologic analyses or stored in $5 \mathrm{mmol} / \mathrm{L}$ butylated hydroxytoluene (BHT) for lipid peroxide determinations. Venous blood was stored frozen for subsequent automated alanine aminotransferase (ALT) measurements.

$\mathrm{H} \& \mathrm{E}-$ and trichrome-stained, paraffin-embedded liver sections were examined by a pathologist (S.-Y.X.) who was blinded to the status of the animal. The degree of steatosis was estimated from digitized images of frozen liver sections stained with oil red $\mathrm{O}$. These images were acquired with a Nikon Diaphot inverted microscope using a blue filter to enhance contrast and an 8-bit CCD camera (Hamamatsu Instruments, Japan). The percentage of the area occupied by oil red Ostained lipid droplets was calculated using Image-1 software (Universal Imaging Co., West Chester, PA), averaging 3-5 separate, randomly selected $40 \times$ fields.

\section{Immunohistochemical Detection of Viral Antigen}

HCV core protein was detected by immunohistochemical analysis of formalin-fixed transgenic liver tissue sections. Endogenous peroxidase activity was blocked by immersing sections in $3 \% \mathrm{H}_{2} \mathrm{O}_{2}$ in phosphate-buffered saline with $0.1 \%$ Tween 20 for 15 minutes, followed by antigen retrieval with $0.3 \%$ pepsin in $0.01 \mathrm{~mol} / \mathrm{L} \mathrm{HCl}$ at $37^{\circ} \mathrm{C}$ for 15 minutes. A murine monoclonal antibody to the $\mathrm{HCV}$ capsid protein, 27D5G5 (generously provided by G. Inchauspé of INSERM Unite 271, Lyon, France) was used as the primary antibody at a dilution of 1:100, followed by incubation with a biotinylated goat anti-mouse immunoglobulin as the secondary antibody (Dako, Carpinteria, CA). Slides were incubated with streptavidin-horseradish peroxidase conjugate, followed by 3-amino9-ethylcarbazole as substrate (Dako), and counterstained with hematoxylin before mounting.

For detection of the E2 protein, frozen sections of the liver were fixed in acetone, blocked with normal goat serum and avidin/biotin (Avidin/Biotin Blocking kit; Vector Laboratories, Burlingame, $\mathrm{CA}$ ), and incubated at $4{ }^{\circ} \mathrm{C}$ overnight with a 1:500 dilution of a rabbit antibody raised to a peptide identical in sequence to the hypervariable region 1 of the E2 protein of HCV-N (S. M. Lemon, unpublished observations, January, 1997). Specificity was confirmed by the parallel staining of tissues with a rabbit antibody specific for a salivary protein of the sand fly, Lutzomyia longipalpis. Endogenous peroxidase activity was depleted with $1 \% \mathrm{H}_{2} \mathrm{O}_{2}$ and $0.1 \%$ sodium azide, and sections were incubated with biotinylated goat anti-rabbit immunoglobulin $(\mathrm{Ig}) \mathrm{G}(1: 200)$ at room temperature for 2 hours. Following incubation with avidin-conjugated peroxidase (Vectastain Elite ABC; Vector Laboratories), and development in $3,3^{\prime}$-diaminobenzidine tetrahydrochloride (DAB) with $0.1 \% \mathrm{H}_{2} \mathrm{O}_{2}$, nuclei were counterstained with hematoxylin.

\section{Apoptosis Assay}

In situ detection of DNA fragmentation was carried out using a fluorescence-based assay (Fluorescein-FragEL, Oncogene Research Products, Boston, MA). Frozen liver sections $(5 \mu \mathrm{m})$ were fixed in $4 \%$ formaldehyde and rehydrated in 20 $\mathrm{mmol} / \mathrm{L}$ Tris-HCL, pH 7.6, $140 \mathrm{mmol} / \mathrm{L} \mathrm{NaCl}$. Sections were digested with proteinase $\mathrm{K}(20 \mu \mathrm{g} / \mathrm{mL})$ for 10 minutes and incubated with terminal deoxynucleotide transferase and fluorescein-labeled nucleoside triphosphates at $37^{\circ} \mathrm{C}$ for $90 \mathrm{~min}-$ utes, then washed in buffer and placed under coverslips in mounting fluid containing 4,6-diamidino-2-phenylindole (DAPI) for counterstaining of nuclei. Slides were examined at an excitation wavelength of $465-495$ or $330-380 \mathrm{nmol} / \mathrm{L}$. Numbers of apoptotic nuclei were counted in each of 10 randomly selected $40 \times$ fields.

\section{Immunocytochemical Detection of Proliferating Hepatocytes}

5-Bromo-2' -deoxyuridine (BrdU) was administered to mice by intraperitoneal injection $(100 \mathrm{mg} / \mathrm{kg}) 5$ hours before necropsy. The liver and small intestines (the latter included as a positive control containing S-phase epithelial cells) were removed at necropsy and fixed in $10 \%$ neutral buffered formalin for paraffin embedding and preparation of sections. Endogenous peroxidase activity was blocked by immersing sections in $0.3 \% \mathrm{H}_{2} \mathrm{O}_{2}$ in methanol for 30 minutes, followed by digestion with $0.05 \%$ pepsin in $0.01 \mathrm{~N} \mathrm{HCl}$. After incubation in $2 \mathrm{~N} \mathrm{HCl}$ for 30 minutes at $37^{\circ} \mathrm{C}$, slides were washed for 10 minutes in $0.1 \mathrm{~mol} / \mathrm{L}$ borax buffer $(\mathrm{pH} 8.5)$ and murine monoclonal anti-BrdU IgG (Becton Dickinson, Franklin Lakes, NJ) applied at a 1:500 dilution overnight at $4^{\circ} \mathrm{C}$. After further washing, slides were incubated with a biotinylated $\mathrm{F}\left(\mathrm{ab}^{\prime}\right) 2$ fragment of sheep anti-mouse IgG (1:100 dilution) for 1 hour, followed by DAB as chromagen. Sections were scored for the number of cells incorporating BrdU as described for apoptosis.

\section{Intrahepatic Lipid Peroxides}

Malonaldehyde and 4-hydroxynonenal concentrations were determined in liver tissue homogenates by a colorimetric assay (LPO-586; OXIS International, Portland, OR). The protein content of the homogenates was determined using a Coomassie blue assay (Pierce, Rockford, IL).

\section{Results}

\section{Transgene Expression in FL-N and S-N Transgenic Mice}

Transgenic mice were designed to express either the full-length $\mathrm{HCV}-\mathrm{N}$ open reading frame (FL-N) or 


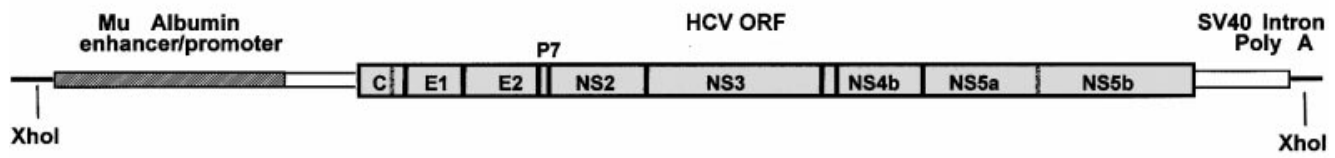

B

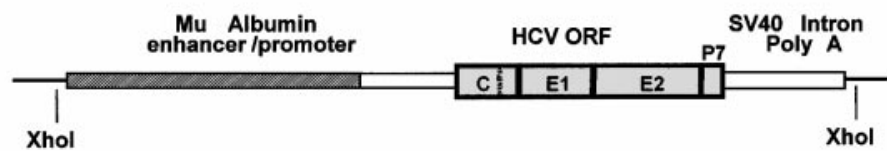

Figure 1. Hepatitis $\mathrm{C}$ transgene organization. $(A)$ The HCV open reading frame within the FL-N transgene encodes the entire polyprotein of a genotype $1 \mathrm{~b}$ strain of HCV. $(B)$ The S-N transgene encodes the amino third of the polyprotein and thus expresses only the structural proteins core, $\mathrm{E} 1$, and E2p7. In each transgene, the HCV open reading frame is under the transcriptional control of the murine albumin promoter/enhancer, and upstream of an SV40 intron/poly(A) addition signal

the segment encoding the structural proteins only (S-N: core and the 2 envelope proteins, E1 and E2-p7; Figure 1). $\mathrm{F}_{1}$ offspring bred from 15 potential FL-N founder animals and 12 potential S-N founder animals were evaluated for mRNA transcription at 2 months of age. Intrahepatic RNA transcripts were not present in an amount detectable by Northern analysis in any of the $\mathrm{F}_{1}$ animals harboring the FL-N transgene (Figure $2 A$ ). In contrast, HCV-specific mRNA was readily detected by Northern analysis of RNA extracted from the liver of animals in 2 of the $12 \mathrm{~S}-\mathrm{N}$ transgenic lineages (S-N/857 and S-N/863; Figure $2 B$ ). In both of these lineages, the

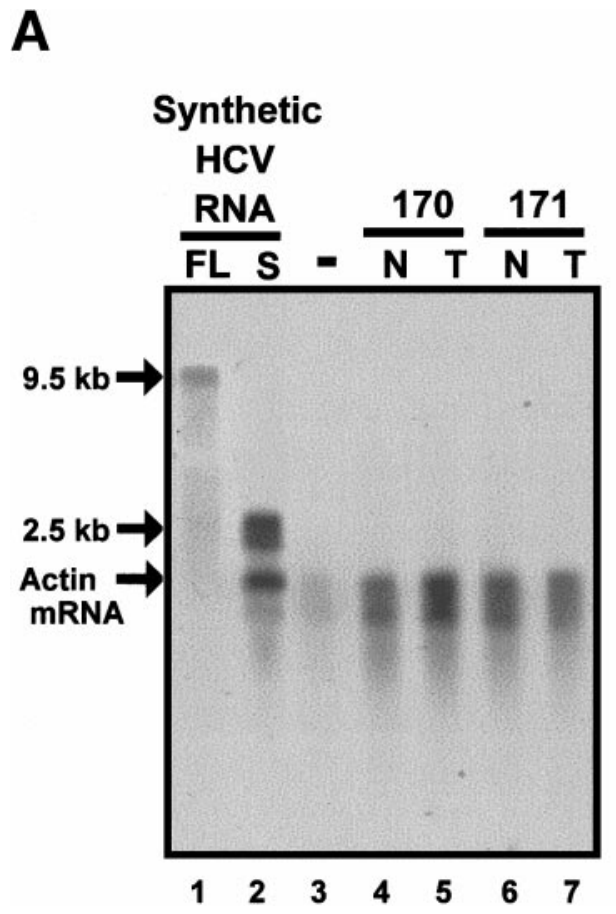

B

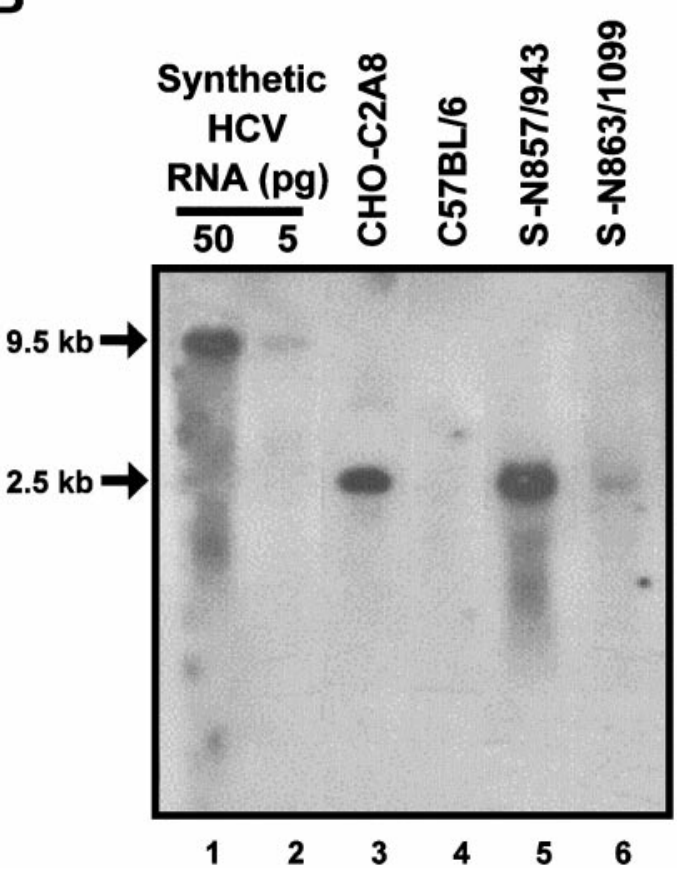

Figure 2. Detection of transgene-specific RNA in transgenic mice by DNA hybridization. $(A)$ No HCV-specific transcripts were detected by Northern analysis of RNA extracted from the livers of animals bearing the FL-N transgene. Shown are results with RNAs extracted from normal liver (N) or tumors (T) in 2 transgenic animals from the FL-N/35 lineage (animals 170 and 171, lanes 4-7). Positive controls included synthetic genome-length RNA (FL, lane 1) and RNA transcripts representing the structural region of the genome only (S, lane 2). Lane 3 contains normal $\mathrm{C} 57 \mathrm{BL} / 6$ mouse RNA. The blot was hybridized with a mixture of DNA probes specific for HCV and mouse actin. (B) Northern detection of $\sim 2.5-\mathrm{kb}$ $\mathrm{HCV}$-specific transcripts in RNA extracted from livers of mice in the S-N/857 and S-N/863 lineages. Gels were loaded with $20 \mu g$ of total RNA purified from mouse liver (lanes 4-6), $0.2 \mu \mathrm{g}$ of mRNA isolated from the stably transformed cell line CHO-C2A8 that expresses a message identical to the S-N transgene (lane 3) or an equivalent amount of normal mouse RNA (lane 4). A total of $50 \mathrm{pg}$ (lane 1) or $5 \mathrm{pg}$ (Iane 2) of 9.5-kb synthetic RNA was mixed with $20 \mu \mathrm{g}$ of normal mouse liver RNA and electrophoresed in parallel as an additional positive control. Hybridization was with a mixture of DNA probes targeting the core sequence. 
Table 1. Summary of HCV Transgenic Mouse Lineages

\begin{tabular}{|c|c|c|c|c|c|}
\hline $\begin{array}{l}\text { Transgene and } \\
\text { lineage }\end{array}$ & \multicolumn{2}{|c|}{ Transgene mRNA expression } & $\begin{array}{c}\text { Transgenic animals } \\
\text { evaluated }(n)\end{array}$ & \multicolumn{2}{|c|}{ Observed histopathology } \\
\hline \multicolumn{6}{|l|}{ Full-length ORF } \\
\hline FL-N/35 & - & + & 73 & + & + \\
\hline FL-N/984 & - & + & 1 & ND & + \\
\hline FL-N/986 & - & + & 10 & + & - \\
\hline S-N/863 & + & + & 89 & + & + \\
\hline S-N/857 & +++ & + & 4 & ND & - \\
\hline S-N/866 & - & + & 2 & ND & + \\
\hline S-N/883 & - & + & 1 & ND & + \\
\hline S-N/888 & - & + & 3 & ND & - \\
\hline
\end{tabular}

${ }^{a} \mathrm{ND}$, not determined, insufficient numbers of animals available.

dominant RNA band was of the expected length $(\sim 2.5$ $\mathrm{kb}$ ), and identical in size to transcripts present in a stable transformed cell line expressing the identical HCV sequence (CHO-C2A8 cells). ${ }^{26}$ Thus, there was no significant splicing of transcripts expressed from the S-N transgene.

Although Northern analyses of the FL-N lineages did not show HCV-specific RNAs, transcription of the transgene was confirmed in 4 of these lineages by RT-PCR using primers designed to amplify the core-E1 region (Table 1). To determine whether a full-length transcript was produced, 9 separate PCR reactions were carried out using primer sets designed to span the entire $\mathrm{HCV}$ polyprotein-coding region and template cDNA produced by RT of RNA from animals in the FL-N/35 lineage (Figure 3). A specific amplification product of the expected size was generated in each reaction, but only after RT of the RNA. Although these results do not exclude the possibility that a proportion of the transcripts are inappropriately spliced, they provide compelling evidence for the presence of full-length RNA encoding the entire polyprotein in these animals. In addition to the 2 $\mathrm{S}-\mathrm{N}$ lineages in which RNA was detectable by Northern analysis (Figure $2 B$ ), liver samples from mice in 3 other S-N lineages also contained HCV-specific RNA detectable by RT-PCR (Table 1).

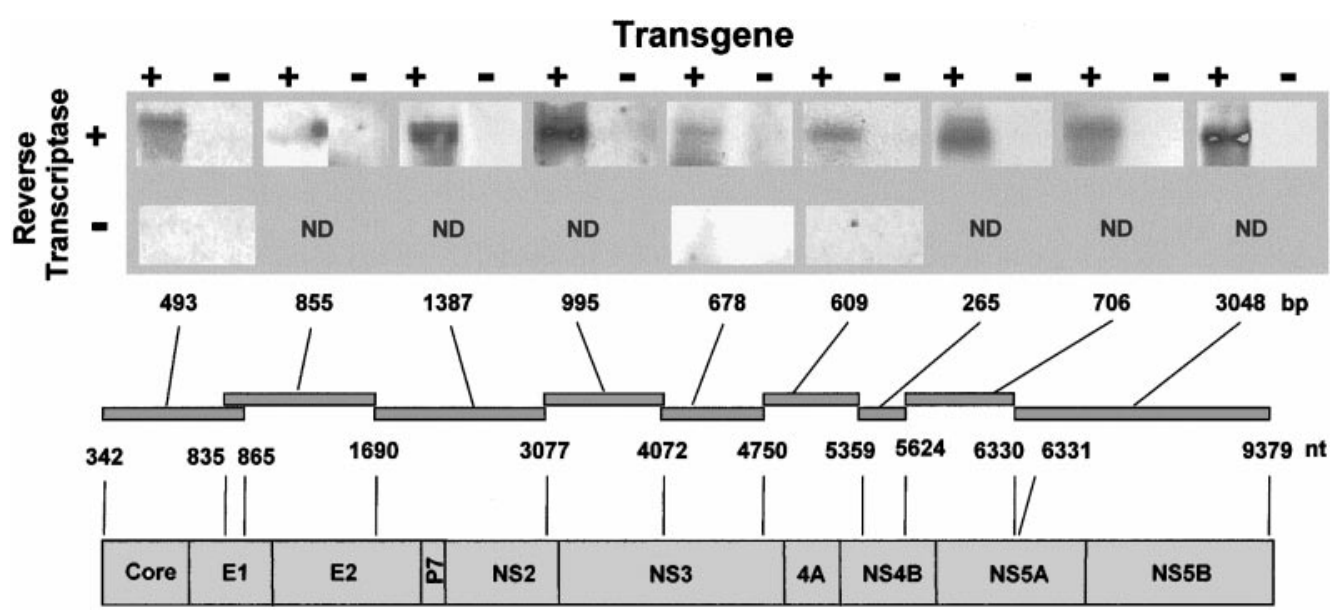

Figure 3. HCV-specific transcripts span the entire polyprotein-coding region in livers of mice from the FL-N/35 lineage. RT-PCR was carried out with 9 nested pairs of oligonucleotide primers amplifying genome segments spanning the entire polyprotein-coding region. The template material was $1 \mu \mathrm{g}$ of total RNA that had been subjected to 2 cycles of DNAse digestion followed by precipitation with lithium chloride to remove cellular DNA. A schematic showing the organization of the polyprotein-coding region is shown at the bottom of the figure. Above it are depicted the cDNA segments amplified by individual primer pairs, the 5' map location of primers (Table 1), and the length of the expected PCR amplimer. Above each is the result of DNA hybridizations of Southern blots of PCR amplimers obtained with RNA from livers of transgenic (transgene +) or nontransgenic (transgene-) mice. Reactions were run with (reverse transcriptase+) or without (reverse transcriptase-) a prior RT reaction to show that $\mathrm{HCV}$-specific sequences were amplified from RNA. 


\section{HCV Protein Expression}

We used the core and E2 proteins as markers for protein expression since both are encoded by the FL-N and $\mathrm{S}-\mathrm{N}$ transgenes (Figure 1). The immunohistochemical detection of core protein in formalin-fixed, transgenic liver tissue is shown in Figure $4 A$ and $B$. Cytoplasmic staining for core antigen was prominent in pericentral hepatocytes in liver from the S-N/857 lineage (Figure $4 B$ ). However, the core protein was not expressed at detectable levels in animals from the S-N/863 lineage, which showed a lower abundance of S-N transcripts than the S-N/857 lineage as determined by Northern analysis (Figure 2B). Similarly, core protein could not be detected in liver tissues from the FL-N lineages (data not shown) in which a low abundance of the full-length open reading frame message was detectable only by RT-PCR (Figures $2 A$ and 3 ). The presence of a detectable abundance of the 21-kilodalton core protein in the S-N/857 lineage, and its absence in the other lineages, was confirmed by immunoblot analysis of liver tissue homogenates. In parallel immunoblots of human tissue, the core protein was detectable in only 1 of 3 patients with chronic hepatitis $C$ (data not shown).

Detection of the E2 protein proved a more sensitive indicator of protein expression. This protein was readily detectable by immunohistochemical techniques when frozen sections of livers from animals in both the S-N/ 857 and S-N/863 lineages were stained with a rabbit antiserum raised to a synthetic peptide representing the hypervariable region of the HCV-N E2 protein (Figure $4 C$ and $E$ ). As with core protein in the S-N/857 lineage, E2 was cytoplasmic in distribution (Figure $4 E$ ) and particularly prominent in pericentral hepatocytes (Figure $4 F)$. Parallel staining of these tissues with a rabbit

Figure 4. Immunohistochemical detection of $\mathrm{HCV}$ structural proteins in livers of mice from $\mathrm{S}-\mathrm{N}$ and FL-N transgenic lineages. $(A, B) \mathrm{Im}$ munoperoxidase detection of HCV core protein in formalin-fixed sections of mouse liver stained with a murine monoclonal antibody to the HCV core protein. $(A)$ Nontransgenic mouse liver showing no expression of core protein $(20 \times$ objective); $(B)$ liver from a transgenic animal in the S-N/857 lineage, showing pericentral distribution of cytoplasmic staining for core antigen in hepatocytes (20x objective). $(C-F)$. Detection of E2 protein in liver of transgenic mice. Liver samples were cryosectioned and stained with a rabbit antibody specific for the E2 protein of HCV-N, followed by a biotinylated secondary antibody and avidin-conjugated peroxidase. Nuclei were counterstained with Gill hematoxylin. (C) Nontransgenic mouse liver (40X objective); $(D)$ transgenic liver from the FL$\mathrm{N} / 35$ lineage ( $40 \times$ objective); $(E)$ transgenic liver from the S-N/863 lineage $(40 \times$ objective); $(F)$ low power view of transgenic liver from the S-N/863 lineage $(10 \times$ objective) showing pericentral distribution of the cytoplasmic E2 antigen. Parallel staining using rabbit antibody specific for an irrelevant antigen (a peptide derived from a salivary protein of sand fly Lutzomyia longipalpis) showed no positively stained cells in the livers of nontransgenic and transgenic mice (data not shown).

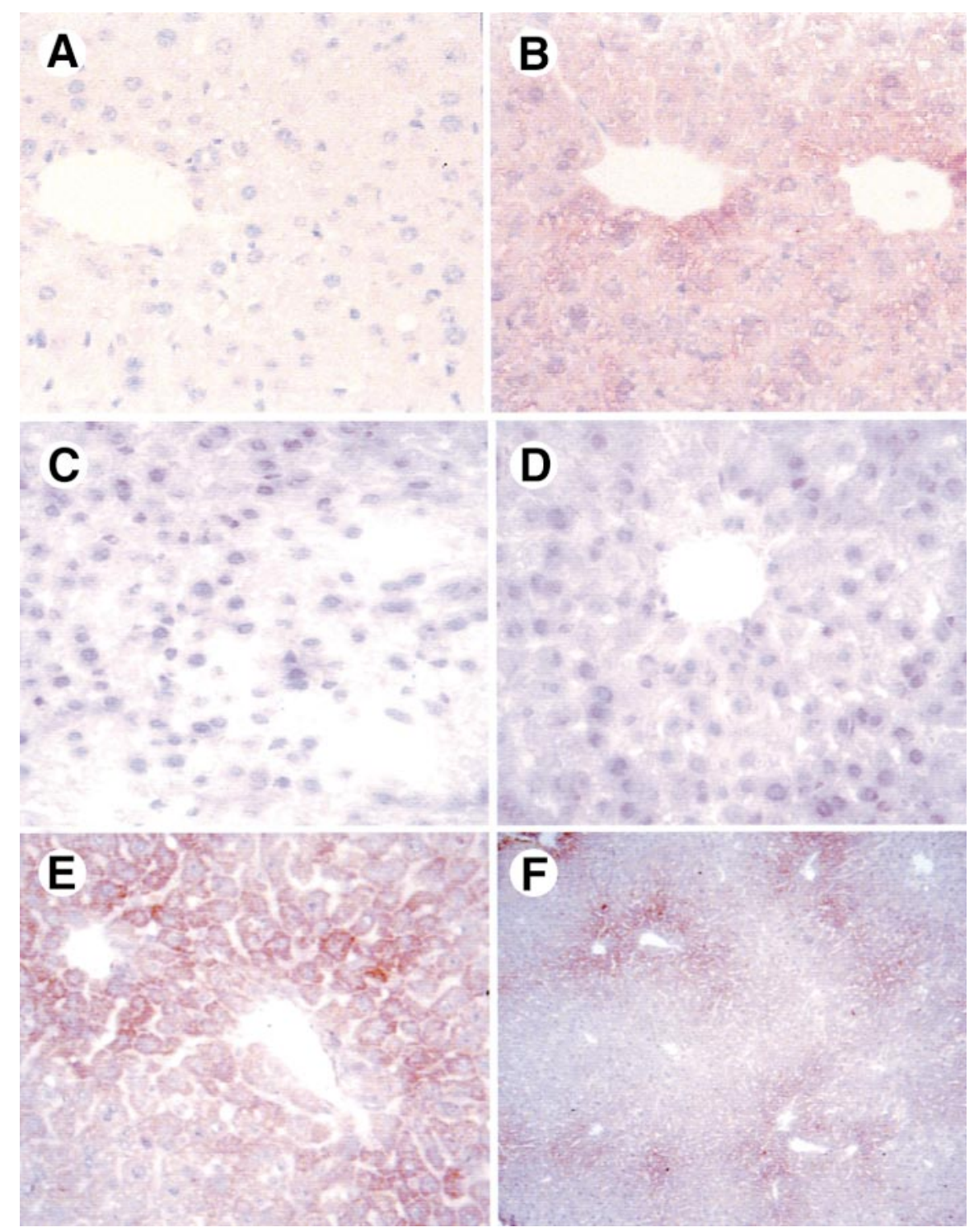


antibody specific for an irrelevant antigen (a peptide derived from a salivary protein of the sand fly Lutzomyia longipalpis) revealed no positively stained cells in the livers of either nontransgenic or transgenic mice (data not shown), confirming the specificity of the antigen detection in the S-N/857 and S-N/863 tissues. In contrast, although faint staining may have been present, liver sections from animals in the FL-N/35 lineage did not contain clearly demonstrable amounts of $\mathrm{E} 2$ protein (Figure 4D). Similar results were obtained with indirect immunofluorescence staining of tissue sections (data not shown). Overall, there was good correlation between transgene mRNA expression levels and the detection of viral proteins (Table 2).

\section{Phenotypes of FL-N and S-N Transgenic Mice}

Of the 9 transgenic lineages with evidence of RNA transcription listed in Table 1 , only 2 proved capable of breeding in large numbers (FL-N/35 and $\mathrm{S}-\mathrm{N} / 863)$. The frequency of transmission of the transgene to $\mathrm{F}_{1}$ and $\mathrm{F}_{2}$ offspring in both lineages approximated $50 \%$, consistent with the results of Southern analysis of tail biopsy DNA, which suggested a single, unique site of transgene integration in each (data not shown).

In general, the transgenic mice appeared normal and did not have demonstrable deficits in growth or development. No cellular inflammatory infiltrate was evident in the livers of these mice, and there were no significant differences in the serum ALT activities of transgenic animals and their nontransgenic littermates (data not shown). However, hepatic steatosis was frequently present in older transgenic animals from the FL-N/35, FL-N/963, and S-N/863 lineages, and transgenic animals in the FL-N/35 and S-N/863 lineages developed HCC. Similar pathology, including HCC, was present in transgenic animals from other lineages, but the frequency of liver disease in these lineages could not be determined because of the limited numbers of animals available (Table 1).

\section{Hepatic Steatosis}

In contrast to a modest degree of steatosis noted occasionally in normal aging $\mathrm{C} 57 \mathrm{BL} / 6$ mice, a substantial proportion of transgenic mice from the FL-N/35 and $\mathrm{S}-\mathrm{N} / 863$ lineages developed moderate to severe steatosis (Figure $5 A$ and $B$ ). This was characterized by a typical vacuolated appearance of lipid-laden hepatocytes in $\mathrm{H} \& \mathrm{E}$-stained sections of the liver (Figure $5 C$ ), and confirmed by the demonstration of increased intrahepatic lipid on oil red O staining of frozen sections (Figure $5 D$ ). Steatosis was primarily centrilobular (Figure $5 B$ ), and either microvesicular or mixed microvesicular/macrovesicular (Figure 5C).

Steatosis increased with age in the transgenic animals and was rare before age 10 months in either lineage. Digitized images of oil red O-stained liver sections were analyzed to quantify the degree of steatosis, with the percent area occupied by oil red O-stained fat droplets estimated in individual liver sections. The area occupied with fat was significantly greater in FL-N/35 transgenic animals $9-15$ months of age than in age-matched, nontransgenic mice ( $P<0.02$ by Student $t$ test; Figure $5 E$ ). Steatosis was significantly more prominent in transgenic males $(19.3 \% \pm 4.4 \% \mathrm{SEM})$ than females $(8.4 \% \pm$ $1.1 \% ; P<0.05)$. A comparable degree of steatosis was documented in a small number of similarly aged transgenic animals from a second, independent FL-N lineage, FL-N/986, and in 12-16-month-old transgenic animals from the S-N/863 lineage (Figure 5E). In the latter lineage, the area occupied by oil red O-stained lipid droplets in transgenic animals significantly exceeded that in sections from age-matched, nontransgenic littermates $(P<0.02)$. Although modest staining with oil red $\mathrm{O}$ was occasionally present in nontransgenic male mice $(6.9 \% \pm 2.3 \%)$, it occupied relatively little of the overall area of the sections from nontransgenic females $3.5 \% \pm$ 2.8\%; $P=\mathrm{NS}$ ). Because Southern blots indicated that the transgene insertion sites are different in these 3 lineages (data not shown), steatosis did not result from fortuitous insertional inactivation of a mouse gene. Its occurrence in the S-N/863 lineage indicates that it can be

Table 2. Summary of Protein Expression Studies in Transgenic Mouse Lineages

\begin{tabular}{|c|c|c|c|c|c|}
\hline \multirow{2}{*}{$\begin{array}{l}\text { Transgene } \\
\text { and lineage }\end{array}$} & \multirow{2}{*}{$\begin{array}{c}\text { mRNA } \\
\text { expression }^{a}\end{array}$} & \multicolumn{2}{|c|}{ Core protein } & \multicolumn{2}{|c|}{ E2 protein } \\
\hline & & Immunohistochemistry & Immunoblot & Immunohistochemistry & Immunofluorescence \\
\hline FL-N/35 & + & - & - & - & - \\
\hline S-N/863 & ++ & - & - & +++ & +++ \\
\hline S-N/857 & +++ & ++ & ++ & +++ & +++ \\
\hline
\end{tabular}

asee Table 1. 

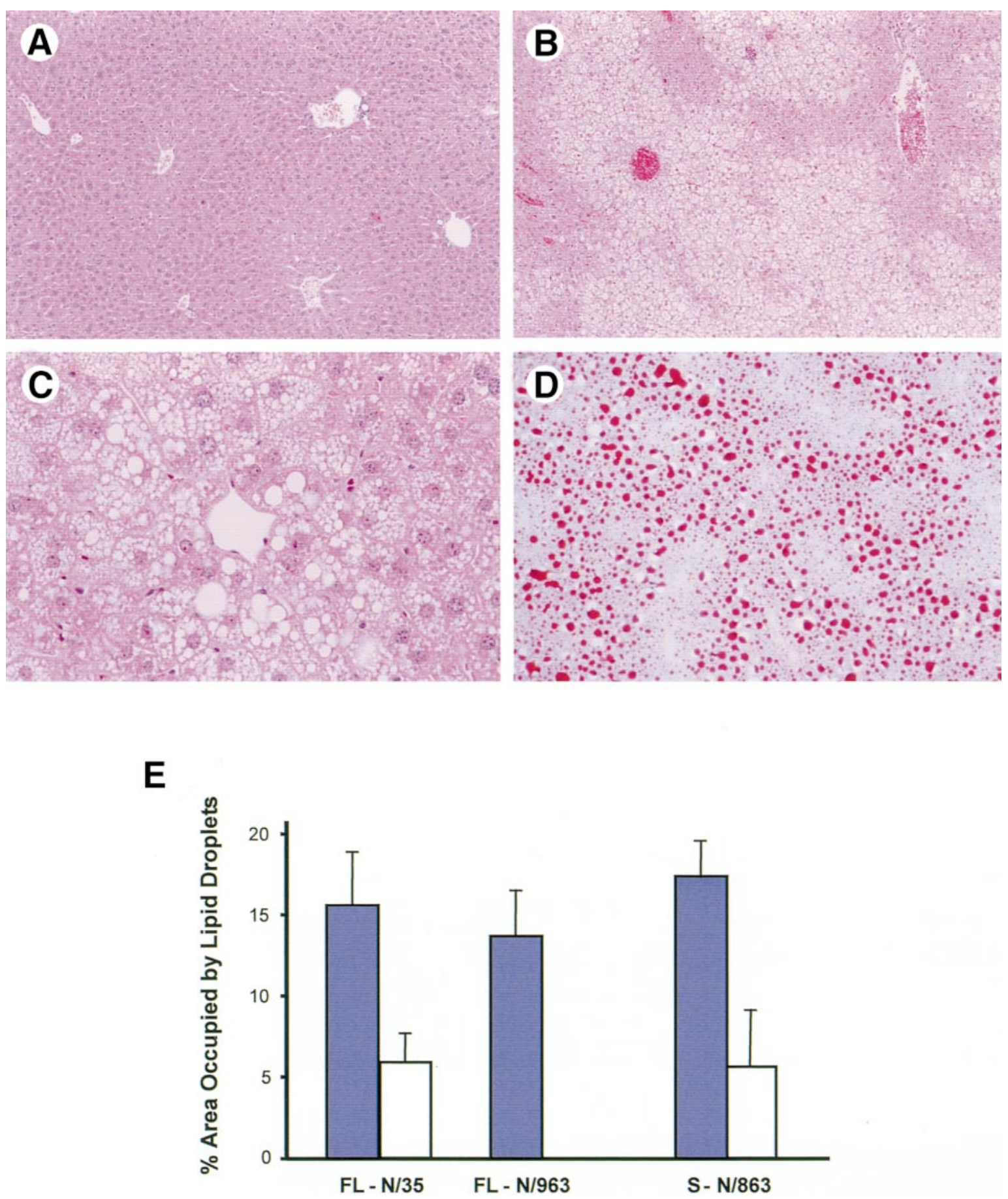

Figure 5. Hepatic steatosis in FL-N/35 lineage mice. $(A)$ Nontransgenic male, age 12 months, H\&E-stained paraffin section showing normal liver histology (10× objective). (B) Transgenic male, age 13 months, H\&E-stained paraffin section (10× objective). Note marked steatosis present diffusely in zones 2 and 3. $(C)$ Higher magnification of the pericentral region of the same liver as shown in $B(40 \times$ objective) showing mixed macrovesicular and microvesicular characteristics of the steatosis. (D) Transgenic male, age 11 months, oil red 0-stained frozen section (10X objective) showing darkly stained lipid droplets in zones 2 and 3. (E) Quantitative analysis of digitized images of oil red 0-stained frozen liver sections. For each liver, the mean percent area occupied by oil red 0-stained lipid droplets was calculated for 3-5 randomly selected fields. Results shown represent the means for transgenic (shaded bars) and nontransgenic (open bars) animals in 3 different lineages: FL-N/35, FL-N/963 (no nontransgenic animals), and S-N/863. For the FL-N/35 lineage, 15 transgenic animals aged 9-15 months (mean age, 12.1 months; $67 \%$ males) were compared with 13 nontransgenic animals of comparable age and sex (mean age, 11.3 months; $69 \%$ males) from the colony ( $P<0.05$ by 2 -sided $t$ test). Results for the FL-N/963 lineage were restricted to 4 transgenic animals, 3 females and 1 male (mean age, 12.3 months). For the S-N/863 lineage, 9 transgenic animals aged 13-16 months (mean age, 14.6 months; $67 \%$ males) were compared with 6 comparably aged nontransgenic littermates (mean age, 14.7 months; $100 \%$ males; $P<0.02$ by $t$ test). Error bars indicate SDs. 
related to the expression of one or more of the structural proteins.

Although centrilobular microvesicular steatosis can result from mitochondrial injury and predispose to increased lipid peroxidation, ${ }^{35}$ there were no significant differences in the basal level of lipid peroxides in nontransgenic animals $(51.1 \pm 4.5 \mathrm{SEM} \mathrm{pmol} / \mathrm{mg}$ protein over the age of 8 months, $\mathrm{n}=24$ ) and in similarly aged FL-N/35 transgenic $(55.6 \pm 8.9 \mathrm{pmol} / \mathrm{mg}, \mathrm{n}=15)$ or $\mathrm{S}-\mathrm{N} / 863$ transgenic animals $(38.9 \pm 8.9 \mathrm{pmol} / \mathrm{mg}$, $\mathrm{n}=15)$.

\section{Hepatic Fibrosis}

Fibrosis is a characteristic pathologic feature of chronic hepatitis C. ${ }^{18,35}$ However, there was no fibrosis in these mouse livers in the absence of cancer. HCC tissues from transgenic animals contained fibrosis evident in trichrome stains (data not shown), as well as prominent activation of stellate cells detectable by immunostaining with a monoclonal antibody specific for $\alpha$-smooth muscle actin $^{36}$ (data not shown). Cells staining specifically for $\alpha$-smooth muscle actin were present only occasionally in non-tumor tissue from these animals, or in transgenic animals without tumors.

\section{Hepatocellular Proliferation and Apoptosis}

Because in vitro studies suggest that HCV proteins may alter cell signaling and regulate apoptotic pathways, ${ }^{23-26}$ we compared transgenic mice from both lineages with their age-matched nontransgenic littermates for evidence of increased or decreased numbers of apoptotic hepatocytes. No consistent differences were apparent. We also compared basal hepatocyte proliferation rates in 9-11-month-old transgenic and nontransgenic mice by assessing the frequency of hepatocytes incorporating BrdU over a 5-hour period before necropsy (Figure 6). Although the highest numbers of proliferating cells were observed in transgenic males from the FL-N/35 lineage (Figure $6 \mathrm{~A}, 3.1 \pm 1.3$ cells per $40 \times$ field compared with $0.82 \pm 0.7$ cells in nontransgenic males from the lineage), this difference did not achieve statistical significance. Somewhat higher numbers of proliferating cells were also present in transgenic mice compared with nontransgenic mice in the S-N/863 lineage (Figure 6B), but this difference also did not achieve statistical significance.

\section{Hepatocellular Carcinogenesis}

Hepatic adenomas or HCC ranging from a few millimeters to more than $2 \mathrm{~cm}$ in diameter were present at necropsy in 5 of 37 FL-N/35 transgenic mice and in 1
A

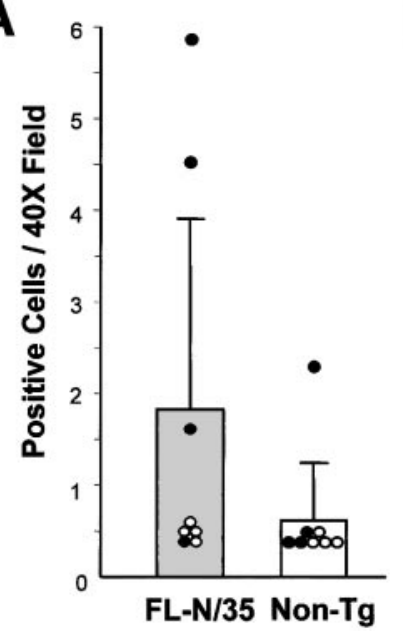

B

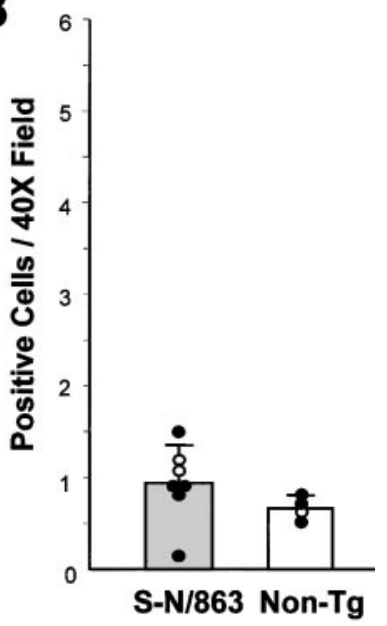

Figure 6. Numbers of hepatocytes showing evidence of DNA synthesis as indicated by BrdU incorporation in 10 randomly selected $40 \times$ fields of liver sections from transgenic and nontransgenic animals. $(A)$ Numbers of hepatocyte nuclei showing BrdU incorporation in $8 \mathrm{FL}-$ N/35 transgenic animals (mean age, 10.0 months) compared with an equal number of age-matched nontransgenic littermates $(P=0.19)$. $(B)$ Numbers of hepatocyte nuclei showing BrdU incorporation in 7 S-N/863 transgenic animals (mean age, 10.6 months) compared with 4 nontransgenic littermates (mean age, 10.7 months; $P=0.12$ ). In each panel, the mean numbers of positive cells are shown separately for transgenic (shaded bars) and nontransgenic (open bars) littermates with values shown for individual male $(\bullet)$ and female $(\bigcirc)$ mice. Error bars represent SDs.

of $42 \mathrm{~S}-\mathrm{N} / 863$ transgenic mice older than 13 months (Table 3). The morphology of the HCCs was variable, with some showing well-differentiated hepatic cords with proliferating hepatocytes and others containing markedly thickened trabeculae or acini of dysplastic hepatocytes with prominent sinusoidal spaces (Figure 7). Multiple tumors were identified in 2 transgenic animals. One liver with a typical carcinoma contained a separate mass with morphology consistent with focal nodular hyperplasia. Focal or diffuse steatosis was sometimes disproportionately present in the adenomas or HCCs (Figure $7 A$ and $C$ ), but there was no apparent correlation between the presence or severity of steatosis and the occurrence of HCC.

All of the tumors identified in transgenic animals occurred in males. Adenomas or HCC were present in 5 of 17 male FL-N/35 transgenic mice older than 13 months, a frequency that was significantly greater than in age-matched female FL-N/35 transgenic animals ( 0 of $20 ; P<0.02$ by Fisher exact test) or in nontransgenic male mice (0 of 24; $P<0.01)$. In contrast, HCC was found in only 1 older transgenic male from the S-N/863 lineage (Table 3). The frequency of tumors in older male S-N/863 transgenic animals (1 of 24) was significantly less than that in comparably aged males in the FL-N/35 
Table 3. Frequency of HCC by Age in Transgenic Lineages

\begin{tabular}{|c|c|c|c|c|c|}
\hline Age $(m o)$ & \multicolumn{2}{|c|}{ FL-N/35 } & \multicolumn{2}{|c|}{ S-N/863 } & $\begin{array}{c}\text { All } \\
\text { nontransgenic }\end{array}$ \\
\hline $7-9$ & $0 / 8$ & $0 / 9$ & $0 / 6$ & $0 / 6$ & $0 / 15$ \\
\hline 10-12 & $0 / 21$ & $0 / 18$ & $0 / 16$ & $0 / 10$ & $0 / 28$ \\
\hline 13-15 & $3 / 20$ & $0 / 5$ & $0 / 19$ & $0 / 25$ & $0 / 30$ \\
\hline $16-18$ & $1 / 13$ & $0 / 8$ & $0 / 15$ & $0 / 7$ & $0 / 15$ \\
\hline All ages & $5 / 73$ & $0 / 47$ & $1 / 89$ & $0 / 66$ & $0 / 115$ \\
\hline$\geq 13$ & $5 / 38$ & $0 / 16$ & $1 / 43$ & $0 / 35$ & $0 / 53$ \\
\hline
\end{tabular}

lineage $(P<0.05)$, and not statistically different from the absence of adenomas or liver cancer in age-matched nontransgenic males. Because the structural proteins of $\mathrm{HCV}$ were expressed at a higher level in the S-N/863 than the FL-N/35 lineage (Figure 4), the greater frequency of cancer in comparably aged mice in the FL$\mathrm{N} / 35$ lineage suggests that the nonstructural proteins of
HCV may contribute to hepatic carcinogenesis even when they are expressed at levels below those detectable by immunohistochemistry. However, a relatively small number of S-N/863 animals were available for necropsy at ages $>18$ months, and further observation is needed to determine the risk of cancer in very old mice in this lineage.
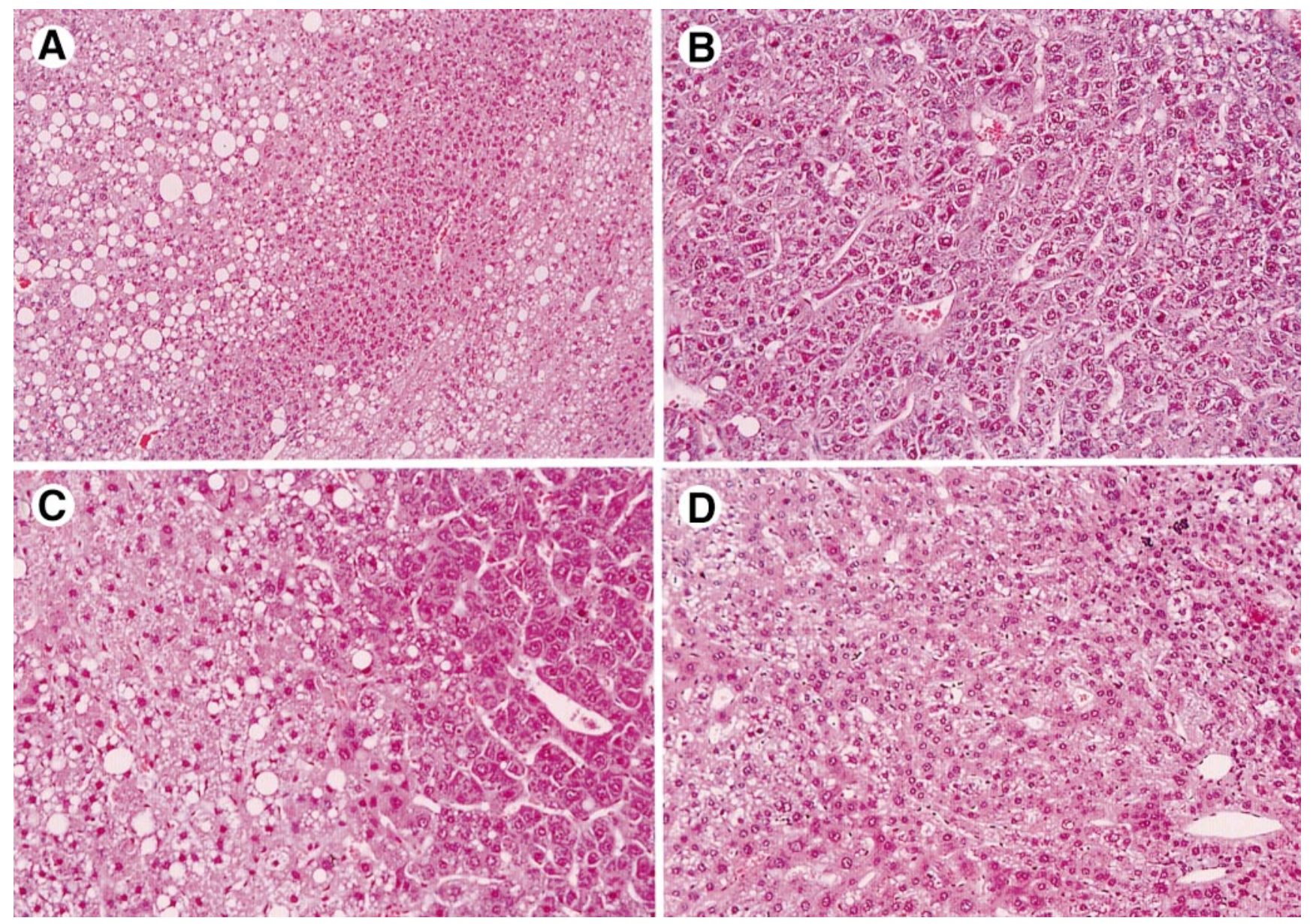

Figure 7. Photomicrographs of liver tumors in HCV-transgenic mice. (A) Small hepatic adenoma, with macrovesicular steatosis at the center, in a 13-month-old male mouse from the FL-N/35 lineage (10× objective). (B) HCC in another 13-month-old male from the FL-N/35 lineage. Note dysplastic hepatocytes forming thickened cellular trabeculae (20× objective). (C) HCC in a third 13-month-old male from the FL-N/35 lineage, with focal steatosis and cytoplasmic hyaline globules in hepatocytes (20× objective). (D) A well-differentiated HCC in an 18-month-old male from the S-N/863 lineage $(20 \times$ objective). 
We examined tumors from the FL-N/35 lineage for evidence of transgene mRNA and antigen expression and found results similar to those obtained with normal transgenic tissue. Specific HCV mRNA was detectable by RT-PCR, and results of Northern analyses of these tissues were repeatedly negative (Figure 2). Neither the core nor the E2 antigens were present in amounts detectable by immunohistochemical techniques.

HCC was not restricted to the FL-N/35 and S-N/863 lineages but also occurred in isolated transgenic animals from other lineages (Table 1). The morphologies of these tumors were similar to those described previously, and all occurred in older male animals (15-17 months old) from lineages with active transcription of the transgene. HCC was not observed in mice from transcriptionally inactive lineages or in nontransgenic animals, including a total of 115 nontransgenic littermates from the FLN/35 and S-N/863 lineages (Table 3). These nontransgenic littermates were caged with transgenic animals and received an identical diet.

\section{Discussion}

The HCV-transgenic mice that we have derived constitutively express low levels of RNA encoding the complete viral polyprotein, or higher levels of the RNA segment encoding only the structural proteins of the virus, under control of a liver-specific promoter. Protein expression was confirmed directly only in the mice expressing the structural region of the polyprotein and was insufficient for detection even with sensitive immunohistochemical techniques in mice with the fulllength reading frame as the transgene. Nonetheless, these FL transgenic animals showed distinctive phenotypes, strongly suggesting the presence of a biologically relevant level of $\mathrm{HCV}$ protein expression. Both types of transgenic mice showed no evidence of inflammation, indicating that they do not mount a significant cellular immune response to expressed viral proteins. Thus, the pathologic findings in these animals, including steatosis in mice of the FL-N/35, FL-N/963, and S-N/863 lineages and the development of liver cancer in older male FL-N/35 mice, arise as a direct result of the expression of viral proteins. These findings suggest that similar nonimmune mechanisms may contribute to the development of steatosis and liver cancer in humans with chronic hepatitis $\mathrm{C}$.

These HCV-transgenic mice are significantly different from those described previously by others. Although Moriya et al. ${ }^{37,38}$ also observed steatosis and HCC in transgenic mice, these animals expressed only the core protein, and not the other structural or nonstructural proteins encoded by the FL-N and S-N transgenes. The core protein interacts with the envelope proteins ${ }^{39}$ and possibly also one or more nonstructural proteins, and such interactions between viral proteins could significantly modulate their effects in vivo. This makes it important to study the activities of $\mathrm{HCV}$ proteins within the context of the entire viral polyprotein rather than in isolation. In addition, the mice described by Moriya et al..$^{37,38}$ appear to express core protein in relatively large amounts because it was readily detectable in immunoblots. This contrasts with the absence of detectable expression of $\mathrm{HCV}$ proteins in the FL-N/35 lineage and the fact that RNA transcripts could be detected in this lineage only by RT-PCR (Figure 3). RT-PCR is routinely required to detect the low levels of HCV RNA transcripts in most patients. Furthermore, viral proteins are not present at amounts detectable in many patients with chronic HCV infection. Although results have varied in different studies, $25 \%-75 \%$ of patients with chronic hepatitis $\mathrm{C}$ do not have levels of core antigen detectable in liver tissue even with sensitive assays using monoclonal antibodies. ${ }^{17,40-42}$ Thus, not only does the FL-N/35 lineage express RNA encoding the full complement of HCV proteins, it is also likely to express the viral proteins at levels mimicking the situation in many infected humans.

Despite the absence of detectable levels of protein expression, liver cancer developed as early as 13 months of age in FL-N/35 mice. In contrast, liver cancers did not occur until 16 months in the core-transgenic mice described by Moriya et al. ${ }^{38}$ However, steatosis was prominent by age 6 months in the transgenic mice studied by Moriya et al. ${ }^{37}$ and was frequently present in females, whereas steatosis was rarely present before age 10 months in FL-N/35 animals and was infrequently seen in females. This latter difference may reflect the higher level of core protein expression in the mice studied by Moriya et al., but it also suggests the absence of a direct link between steatosis and carcinogenesis. It further suggests that HCV proteins other than core may promote the development of cancer. This conclusion is reinforced by the low rate of cancer in 13-18-month-old S-N/863 lineage animals compared with that observed in the FL-N/35 lineage (Table 1). Dysregulation of cell growth has been associated with the expression of core in cultured cells, ${ }^{24-26,43}$ but potential roles in carcinogenesis have also been suggested for the NS3 and NS5A proteins. ${ }^{27,44}$ These proteins are encoded by the FL-N/35 transgene, and the higher rate of cancer in this lineage suggests that even very low-level expression of these proteins may contribute to hepatocellular carcinogenesis. 
Further observation of the S-N/863 lineage is needed to determine whether these transgenic mice are at increased risk for liver cancer at ages greater than 16-18 months.

Both the mice described by Moriya et al. ${ }^{37,38}$ and those described here were developed within a predominantly C57BL/6 genetic background. This may be important to the disease observed in these animals; 2 other groups of investigators, Kawamura et al. ${ }^{45}$ and Pasquinelli et al., ${ }^{46}$ found no pathology in transgenic mice expressing the core protein of $\mathrm{HCV}$ in different genetic backgrounds. Others have noted that normal aging $\mathrm{C} 57 \mathrm{BL} / 6$ mice are at risk for the development of mild steatosis, ${ }^{47}$ a phenomenon we confirmed in our animals (Figure $5 E$ ). Thus it is possible that HCV gene expression may act to exacerbate an underlying metabolic abnormality in $\mathrm{C} 57 \mathrm{BL} / 6$ mice that is not present in other inbred strains of mice. If genetic background is proven to be an important factor in determining disease expression in HCVtransgenic mice, it may provide useful clues to the mechanisms underlying the variable risk of disease in persons with chronic HCV infection.

Although it is not clear which HCV protein(s) promote steatosis in the FL-N/35 mice, its occurrence in the S-N/863 lineage indicates the involvement of one or more structural proteins. This is consistent with the occurrence of steatosis in transgenic animals that express only high levels of the core protein. ${ }^{38}$ Core protein physically associates with cytoplasmic lipid droplets through an interaction with apolipoprotein A2, and this may alter normal lipid transport leading to steatosis. ${ }^{22,48}$ However, steatosis was at least as prominent in the FL-N/35 lineage as the S-N/863 lineage (Figure 5E), despite the absence of a detectable abundance of $\mathrm{HCV}$ structural proteins in the former (Figure $4 D$ ). This raises the possibility that very low-level expression of one of the nonstructural proteins encoded by the transgene in the FL-N/35 or FL-N/963 animals may have contributed to steatosis. NS5A has recently been found to interact with apolipoprotein A1 and to colocalize with the core protein on cytoplasmic lipid droplets (Stephanie T. Shi and Michael M. C. Lai, personal communication, April 2001). Thus it is possible that this interaction further promotes the accumulation of intracellular lipids induced by core.

Alternatively, core protein is capable of interacting with the cytoplasmic domain of several members of the tumor necrosis factor receptor family. ${ }^{25,43}$ The consequences of this interaction are controversial but could include constitutive activation of proapoptotic cell signaling, leading to a mitochondrial permeability transition and subsequent oxidative stress. ${ }^{49,50}$ However, we did not find increased rates of hepatocellular apoptosis in our mice. Yet a third possibility is that the core protein could interact directly with mitochondria. ${ }^{38}$ We recently found that the expression of core protein leads to demonstrable mitochondrial injury with attendant increases in the abundance of reactive oxygen species in several types of cultured cells. ${ }^{51}$ The centrilobular (zone 3) microvesicular steatosis observed in these mice could reflect such mitochondrial injury. As reported here, we found no increases in the basal levels of lipid peroxides in the livers of mice from either the FL-N/35 or S-N/863 lineages. However, we have documented elevated levels of intrahepatic lipid peroxidation products in transgenic S-N/ 863 mice after low-dose carbon tetrachloride exposure. ${ }^{51}$ These results suggest that these transgenic mice are at increased risk of tissue damage in the face of oxidative stress. The accumulation of reactive oxygen species resulting from mitochondrial dysfunction could contribute to carcinogenesis by promoting chromosomal DNA damage and altering the regulation of apoptosis. ${ }^{35}$ In addition to the core protein, ${ }^{52}$ the generation of intracellular reactive oxygen species has been linked recently to expression of the NS5A protein, providing yet another potential explanation for the increase in hepatic carcinogenesis we observed with the inclusion of the HCV nonstructural proteins among those encoded by the transgene in the FL-N/35 animals.

In addition to these potential nonimmune mechanisms of liver injury, chronic inflammation associated with the cellular immune response to $\mathrm{HCV}$ infection is likely to play an important role in the development of HCC in humans. Inflammation would be expected to exacerbate oxidative stress induced by the expression of viral proteins in an already vulnerable liver, potentially accelerating the progression to hepatocellular carcinogenesis. Nonetheless, the results described here show that the intrahepatic expression of HCV proteins directly promotes the development of steatosis and significantly enhances the risk of liver cancer in the absence of inflammation, and provide novel evidence for the involvement of the nonstructural proteins of HCV in these pathogenetic processes.

\section{References}

1. Choo Q-L, Kuo G, Weiner AJ, Overby LR, Bradley DW, Houghton M. Isolation of a cDNA clone derived from a blood-borne non-A, non-B viral hepatitis genome. Science 1989;244:359-362.

2. Alter MJ, Margolis HS, Krawczynski K, Judson FN, Mares A, Alexander WJ, Hu PY, Miller JK, Gerber MA, Sampliner RE, Meeks EL, Beach MJ. The natural history of community-acquired hepatitis C in the United States. N Engl J Med 1992;327:1899-1905.

3. Seeff LB, Buskell-Bales Z, Wright EC, Durako SJ, Alter HJ, Iber FL, Hollinger FB, Gitnick G, Knodell RG, Perrillo RP, Stevens CE, Hollingsworth CG, NHLBI Study Group. Long-term mortality after 
transfusion-associated non-A, non-B hepatitis. N Engl J Med 1992;327:1906-1911.

4. Seeff LB. Natural history of hepatitis C. Hepatology 1997;26: 21S-28S.

5. Di Bisceglie AM, Simpson LH, Lotze MT, Hoofnagle JH. Development of hepatocellular carcinoma among patients with chronic liver disease due to hepatitis C viral infection. J Clin Gastroenterol 1994;19:222-226.

6. Kiyosawa K, Furuta S. Hepatitis C virus and hepatocellular carcinoma. In: Reesink HW, ed. Hepatitis C virus. Basel, Switzerland: Karger, 1994:98-120.

7. Kiyosawa K, Sodeyama T, Tanaka E, Gibo Y, Yoshizawa K, Nakano Y, Furata S, Akahane Y, Nishioka K, Purcell RH, Alter HJ. Interrelationship of blood transfusion, non-A, non-B hepatitis and hepatocellular carcinoma: analysis by detection of antibody to hepatitis C virus. Hepatology 1990;12:671-675.

8. Alter MJ, Mast EE, Moyer LA, Margolis HS. Hepatitis C. Infect Dis Clin North Am 1998;12:13-26.

9. McHutchison JG, Gordon SC, Schiff ER, Shiffman ML, Lee WM, Rustgi VK, Goodman ZD, Ling MH, Cort S, Albrecht JK. Interferon alfa-2b alone or in combination with ribavirin as initial treatment for chronic hepatitis C. Hepatitis Interventional Therapy Group. N Engl J Med 1998;339:1485-1492.

10. Schalm SW, Hansen BE, Chemello L, Bellobuono A, Brouwer JT, Weiland O, Cavalletto L, Schvarcz R, Ideo G, Alberti A. Ribavirin enhances the efficacy but not the adverse effects of interferon in chronic hepatitis C-meta-analysis of individual patient data from European centers. J Hepatol 1997;26:961-966.

11. Lemon SM, Chisari FV, Lai MM, Nishioka K, Mishiro S, Johnson L. The Nineteenth United States-Japan Joint Hepatitis Panel Meeting. Hepatology 1998;28:881-887.

12. Koziel MJ, Dudley D, Wong JT, Dienstag J, Houghton M, Ralston R, Walker BD. Intrahepatic cytotoxic T lymphocytes specific for hepatitis $C$ virus in persons with chronic hepatitis. J Immunol 1992;149:3339-3344.

13. Cerny A, Chisari FV. Pathogenesis of chronic hepatitis C: immunological features of hepatic injury and viral persistence. Hepatology 1999;30:595-601.

14. Nakamoto Y, Guidotti LG, Kuhlen CV, Fowler P, Chisari FV. Immune pathogenesis of hepatocellular carcinoma. J Exp Med 1998;188:341-350.

15. Rubbia-Brandt L, Quadri R, Abid K, Giostra E, Male PJ, Mentha G, Spahr L, Zarski JP, Borisch B, Hadengue A, Negro F. Hepatocyte steatosis is a cytopathic effect of hepatitis C virus genotype 3 . J Hepatol 2000;33:106-115.

16. Scheuer PJ, Davies SE, Dhillon AP. Histopathological aspects of viral hepatitis. J Viral Hepat 1996;3:277-283.

17. Fujie H, Yotsuyanagi $H$, Moriya $K$, Shintani $Y$, Tsutsumi $T$, Takayama T, Makuuchi M, Matsuura Y, Miyamura T, Kimura S, Koike $\mathrm{K}$. Steatosis and intrahepatic hepatitis $\mathrm{C}$ virus in chronic hepatitis. J Med Virol 1999;59:141-145.

18. Goodman ZD, Ishak KG. Histopathology of hepatitis C virus infection. Semin Liver Dis 1995;15:70-81.

19. Fischer HP, Willsch E, Bierhoff E, Pfeifer U. Histopathologic findings in chronic hepatitis C. J Hepatol 1996;24:35-42.

20. Schiff ER. Hepatitis C and alcohol. Hepatology 1997;26:39S$42 \mathrm{~S}$.

21. Thomas DL, Astemborski J, Rai RM, Anania FA, Schaeffer M, Galai N, Nolt K, Nelson KE, Strathdee SA, Johnson L, Laeyendecker O, Boitnott J, Wilson LE, Vlahov D. The natural history of hepatitis $C$ virus infection: host, viral, and environmental factors. JAMA 2000;284:450-456.

22. Barba G, Harper F, Harada T, Kohara M, Goulinet S, Matsuura Y, Eder G, Schaff Z, Chapman MJ, Miyamura T, Bréchot C. Hepatitis $C$ virus core protein shows a cytoplasmic localization and associates to cellular lipid storage droplets. Proc Natl Acad Sci U S A 1997;94:1200-1205.
23. Ray RB, Lagging LM, Meyer K, Ray R. Hepatitis C virus core protein cooperates with ras and transforms primary rat embryo fibroblasts to tumorigenic phenotype. J Virol 1996;70:44384443.

24. Ray RB, Meyer K, Ray R. Suppression of apoptotic cell death by hepatitis C virus core protein. Virology 1996;226:176-182.

25. Zhu N, Khoshnan A, Schneider R, Matsumoto M, Dennert G, Ware C, Lai MM. Hepatitis C virus core protein binds to the cytoplasmic domain of tumor necrosis factor (TNF) receptor 1 and enhances TNF-induced apoptosis. J Virol 1998;72:3691-3697.

26. Honda M, Kaneko S, Shimazaki T, Matsushita E, Kobayashi K, Ping LH, Zhang HC, Lemon SM. Hepatitis C virus core protein induces apoptosis and impairs cell-cycle regulation in stably transformed Chinese hamster ovary cells. Hepatology 2000;31: 1351-1359.

27. Sakamuro D, Furukawa T, Takegami T. Hepatitis C virus nonstructural protein NS3 transforms NIH 3T3 cells. J Virol 1995;69: 3893-3896.

28. Alter HJ, Holland PV, Purcell RH, Popper H. Transmissible agent in non-A, non-B hepatitis. Lancet 1978;1:459-463.

29. Tabor E, Gerety RJ, Drucker JA, Seeff LB, Hoofnagle JH, Jackson DR, April M, Barker LF, Pineda-Tamondong G. Transmission of non-A, non-B hepatitis from man to chimpanzee. Lancet 1978;1: 463-466.

30. McPherson CE, Shim E-Y, Friedman DS, Zaret KS. An active, tissue-specific enhancer and bound transcription factors existing in a precisely positioned nucleosomal array. Cell 1993;75:387398.

31. Hayashi N, Higashi H, Kaminaka K, Sugimoto H, Esumi M, Komatsu K, Hayashi K, Sugitani M, Suzuki K, Tadao O, Mizuno K, Shikata T. Molecular cloning and heterogeneity of the human hepatitis C virus (HCV) genome. J Hepatol 1993;17:S94-S107.

32. Beard MR, Abell G, Honda M, Carroll A, Gartland M, Clarke B, Suzuki K, Lanford R, Sangar DV, Lemon SM. An infectious molecular clone of a Japanese genotype $1 \mathrm{~b}$ hepatitis $\mathrm{C}$ virus. Hepatology 1999;30:316-324.

33. Lemon SM, Lerat $\mathrm{H}$, Weinman SA, Honda M. A transgenic mouse model of steatosis and hepatocellular carcinoma associated with chronic hepatitis C virus infection in humans. Trans Am Clin Climatol Assoc 2000;111:146-156.

34. Whitby K, Garson JA. A single tube two compartment reverse transcription polymerase chain reaction system for ultrasensitive quantitative detection of hepatitis C virus RNA. J Virol Methods 1997;66:15-18.

35. Lemasters JJ, Nieminen AL. Mitochondrial oxygen radical formation during reductive and oxidative stress to intact hepatocytes. Biosci Rep 1997;17:281-291.

36. Friedman SL. Molecular regulation of hepatic fibrosis, an integrated cellular response to tissue injury. J Biol Chem 2000;275: 2247-2250.

37. Moriya K, Yotsuyanagi H, Shintani $Y$, Fujie H, Ishibashi K, Matsuura $\mathrm{Y}$, Miyamura T, Koike K. Hepatitis C virus core protein induces hepatic steatosis in transgenic mice. J Gen Virol 1997; 78:1527-1531.

38. Moriya K, Fujie H, Shintani Y, Yotsuyanagi H, Tsutsumi T, Ishibashi K, Matsuura Y, Kimura S, Miyamura T, Koike K. The core protein of hepatitis $C$ virus induces hepatocellular carcinoma in transgenic mice. Nat Med 1998;4:1065-1067.

39. Lo SY, Selby MJ, Ou JH. Interaction between hepatitis C virus core protein and E1 envelope protein. J Virol 1996;70:51775182.

40. Yap SH, Willems M, Van den Oord J, Habets W, Middeldorp JM, Hellings JA, Nevens F, Moshage H, Desmet V, Fevery J. Detection of hepatitis $C$ virus antigen by immuno-histochemical staining: a histological marker of hepatitis C virus infection. J Hepatol 1994; 20:275-281.

41. Gonzalez-Peralta RP, Fang JW, Davis GL, Gish R, Tsukiyama- 
Kohara K, Kohara M, Mondelli MU, Lesniewski R, Phillips MI, Mizokami M. Optimization for the detection of hepatitis $\mathrm{C}$ virus antigens in the liver. J Hepatol 1994;20:143-147.

42. Hiramatsu N, Hayashi N, Haruna $Y$, Kasahara A, Fusamoto $H$, Mori C, Fuke I, Okayama H, Kamada T. Immunohistochemical detection of hepatitis $\mathrm{C}$ virus-infected hepatocytes in chronic liver disease with monoclonal antibodies to core, envelope and NS3 regions of the hepatitis C virus genome. Hepatology 1992;16: 306-311.

43. Chen CM, You LR, Hwang LH, Lee YH. Direct interaction of hepatitis $\mathrm{C}$ virus core protein with the cellular lymphotoxin-beta receptor modulates the signal pathway of the lymphotoxin-beta receptor. J Virol 1997;71:9417-9426.

44. Gale MJ, Kwieciszewski B, Dossett M, Nakao H, Katze MG. Antiapoptotic and oncogenic potentials of hepatitis $C$ virus are linked to interferon resistance by viral repression of the PKR protein kinase. J Virol 1999;73:6506-6516.

45. Kawamura T, Furusaka A, Koziel MJ, Chung RT, Wang TC, Schmidt EV , Liang TJ. Transgenic expression of hepatitis C virus structural proteins in the mouse. Hepatology 1997;25:10141021.

46. Pasquinelli C, Shoenberger JM, Chung J, Chang KM, Guidotti LG, Selby M, Berger K, Lesniewski R, Houghton M, Chisari FV. Hepatitis $\mathrm{C}$ virus core and $\mathrm{E} 2$ protein expression in transgenic mice. Hepatology 1997;25:719-727.

47. Blake WL, Ulrich RG, Marotti KR, Melchior GW. The development of fatty liver is accelerated in transgenic mice expressing cynomolgus monkey cholesteryl ester transfer protein. Biochem Biophys Res Commun 1994;205:1257-1263.

48. Sabile A, Perlemuter G, Bono F, Kohara K, Demaugre F, Kohara M, Matsuura Y, Miyamura T, Brechot C, Barba G. Hepatitis C virus core protein binds to apolipoprotein All and its secretion is modulated by fibrates. Hepatology 1999;30:1064-1076.
49. Bradham CA, Qian T, Streetz K, Trautwein C, Brenner DA, Lemasters $\mathrm{JJ}$. The mitochondrial permeability transition is required for tumor necrosis factor alpha-mediated apoptosis and cytochrome c release. Mol Cell Biol 1998;18:6353-6364.

50. Lemasters JJ. The mitochondrial permeability transition: from biochemical curiosity to pathophysiological mechanism. Gastroenterology 1998;115:783-786.

51. Okuda M, Li K, Beard MR, Showalter LA, Scholle F, Lemon SM, Weinman SA. Mitochondrial injury, oxidative stress and antioxidant gene expression are induced by hepatitis C virus core protein. Gastroenterology 2002;122:366-375.

52. Gong G, Waris G, Tanveer R, Siddiqui A. Human hepatitis C virus NS5A protein alters intracellular calcium levels, induces oxidative stress, and activates STAT-3 and NF-kappa B. Proc Natl Acad Sci U S A 2001;98:9599-9604.

Received May 14, 2001. Accepted October 8, 2001.

Address requests for reprints to: Stanley M. Lemon, M.D., Department of Microbiology and Immunology, The University of Texas Medical Branch, 301 University Boulevard, Galveston, Texas 77555-1019. e-mail: smlemon@utmb.edu; fax: (409) 772-3757.

Dr. Lerat's present address: Institut de Génétique Moléculaire, CNRS, Montpellier, France. Dr. Gosert's present address: Institute for Medical Microbiology, University of Basel, Basel, Switzerland.

Supported in part by the National Institute of Allergy and Infectious Diseases (U19-Al40035). H.L. was the recipient of a McLaughlin Fellowship from the University of Texas Medical Branch.

The authors thank Annette Martin for critically reviewing the manuscript, Brian West for assistance in the interpretation of histopathology, Elbert Whorton for assistance with statistical analysis, and Li-Hua Ping and Geneviêve Inchauspé for generously providing HCV-specific antibodies.

Drs. Lerat and Honda contributed equally to this work. 